\title{
社会的苦境場面における言語的印象管理方略 多次元尺度法によるアプローチー
}

早稲田大学 古屋健・湯田彰 夫 $^{1}$

Verbal strategies for impression management in social predicaments :

A multidimensional approach

Takeshi Furuya and Akio Yuda (Department of Educational Psychology, School of Education, Waseda University, Shinjuku-ku, Tokyo 160)

The objects of the present study are to classify ordinary social predicaments and to examine the relationships between the perceptions of those predicaments and the verbal strategies for impression management. One hundred and twenty male undergraduates were asked to rate 15 social predicaments on 20 9-point scales. The ratings were analysed by SUMSCAL procedure, and based on the extracted dimensions social predicaments were classified by the cluster method. The subjects were also required to describe their verbal responses (e. g. excuses) as offenders in each situation. Correlations between clusters and verbal responses were examined. The results indicated that; (a) three dimensions were found to underlie perception of social predicaments-controllability, affective responsiveness, and offensiveness; (b) social predicaments were grouped into five clusters ; (c) the clusters closely correlated with the subjects' verbal responses. These results showed that the impression management strategies selected by the offender in social predicaments were determined by their perceptions of the situations.

Key words : accounts, impression management, self-presentation, multidimensional scaling, social situations, social interactions.

社会的相互作用の過程で，人が維持すべき印象に対し て何かしら望ましくない意味合いを持つ事態が発生し， 他者によってその人に責任があると判断される可能性の ある場面を, Schlenker (1980) は社会的苦境（social predicament）と呼んでいる. 日常的な相互作用場面で 社会的苦境が発生する最も典型的な事態は, 何らかの理 由で人が自ら呈示しょうとした印象と相反する意味を内 包する行動をとった場合である.そのよらな行動がなさ れると, それまでの関係性に基づいた相互作用の流れは 妨げられ, 維持することが不可能になる. その結果, 相 互作用参加者は妨害の原因となる行動を起こした侵犯者 (offender) とその行動によって妨害を受けた被害者 (victim) とに分かれて相対することになり，相互作用 を続けるためには両者の間に新たな関係を確立し直す必 要が生ずる. 日常的な社会的苦境では, 関係の再確立の 契機として，被害者が侵犯者に対してその行動を説明す るよう要求したり, あるいは侵犯者の方から被害者に対 して自分の行動を説明する機会を与えてくれるよう求め るのが普通である. そのような場面で侵犯者が呈示する 行動の公的説明が印象管理の上で重要な働きをしている

1 本論文作成に当たり早稲田大学教育学部橋本仁司教 授にご指導頂きました。ここに記して厚くお礼申し上げ ます。
ことは, Mills (1940) をはじめとする多くの研究者が 指摘するところである (Goffman, 1955； Scott \& Lyman, 1968; Semin \& Manstead, 1983 ; Tedeschi \& Reiss，1981). 侵犯者はその際さまざまな方略を用 いて自分の維持すべき印象を守り,できるだけ有利な形 で関係を再確立しょうと試みる。本研究では Tedeschi \& Reiss (1981) 朔い，これを社会的苦境場面に晾け る言語的印象管理方略と呼ぶ.

社会的苦境に和ける言語的印象管理方略の種類につい ては、これまでさまざまな分類が試みられてきた（部分 的分類として Scott \& Lyman, 1968; Sykes \& Matza, 1957 ; 包括的分類として Schonbach, 1980 ; Semin \& Manstead, 1983; Tedeschi \& Reiss, 1981). それら を総括的に検討した Semin \& Manstead (1983) によ れば, 社会的苦境に陥った侵犯者の取る方略は, 行動の 侵犯度と自分の責任を認めるか否かによって（a）謝 罪 (apology), (b) 言い訳 (excuse), (c) 正当化 (justification) の 3 つのカゴリーに大別される.

ところで, 社会的苦境に宿った侵犯者が直面する最大 の問題は, これらの方略の中から自分に最も有利な結果 を導く選択をすることである. 日常的な社会的苦境にお ける侵犯者の方略選択や選択された方略の効果について 検討したこれまでの研究では, 行動の侵犯度 (Felson 
Table 1

刺激場面リスト

\begin{tabular}{|c|c|c|c|}
\hline 記号 & 略 & 称 & 社 会 的 苦 境 場 面 \\
\hline A & 交通事 & & Aさんはドライブ中, 飛び出してきた歩行者をひいてケガをさせました. \\
\hline B & 自転 & 車 & Aさんが駐輪場の鍵のかかっていない自転車に乗ろうとした所に，持ち主が現れました. \\
\hline $\mathrm{C}$ & カ & ラ & Aさんは友人から借りたカメラを壞してしまいました。 \\
\hline $\mathrm{D}$ & デ - & ト & Aさんはデートの約束をしていて, 待ち合わせの時間に遅れてしまいました. \\
\hline $\mathrm{E}$ & 婚約 破 & & Aさんは結納までかわした相手との婚約を破裹することにしました。 \\
\hline $\mathrm{F}$ & 電 & 車 & Aさんは電車の中で，隣の人の足を踏んでしまいました。 \\
\hline G & 宿 & 題 & Aさんは締切日を過ぎても宿題のレポートを提出せず，先生から注意されました. \\
\hline $\mathrm{H}$ & 家庭教 & & Aさんはアルバイトの家庭教師を無断で休んでしまいました. \\
\hline I & 映 & 画 & Aさんは友人に勧めて一緒に映画を見に行きましたが, 非常につまらない作品でした. \\
\hline $\mathrm{J}$ & 名 & 前 & Aさんは人と会話中，相手の名前を間違えて呼んでしまいました. \\
\hline $\mathrm{K}$ & 宴 & 会 & Aさんは宴会の席上, ビールの入ったコップを倒して友人の服を污してしまいました. \\
\hline $\mathrm{L}$ & 会 & 議 & Aさんは会議で自分の意見に反対した同僚をなぐってケガを負わせました。 \\
\hline M & レストラ & & Aさんはレストランで食事をした後，レジの所でお捦が足りないことに気が付きました. \\
\hline $\mathrm{N}$ & 間違い電 & & Aさんは友人に電話をかけようとして，知らない人の家にかかってしまいました。 \\
\hline $\mathrm{O}$ & 悪 & 口 & Aさんが人の悪口を言っていたら，そばで本人に聞かれていました。 \\
\hline
\end{tabular}

\& Ribner, 1981 ; Darby \& Schlenker, 1982), その 責任が侵犯者に帰属される程度 (Blumstein, 1974 ; Darby \& Schlenker, 1982), 侵犯者と被害者の相対的 地位関係 (Blumstein, 1974; Ungar, 1981) 等が重要 な要因として取上げられている. しかし，これらの研究 では検討された場面, 行動, 方略が限られていたり染意 的であるために，その知見から多様な社会的苦境での方 略選択を総合的に把握することはきわめて困難である.

そこで本研究では, 多次元尺度法を用いて侵犯者の社 会的苦境認知を規定している次元を抽出し, 抽出された 次元と言語的印象管理方略の選択傾向との関連を分析し た. 多次元尺度法は人々が社会的状況を弁別したり評価 する際に用いる潜在的な認知次元を抽出する有効な方法 として, 近年多くの研究に利用されている. それらの研 究を概観すると, 個人は一定の認知次元に基ついて社会 的状況を弁別して未り, 社会的状況はその認知次元が構 成する多次元空間の中に位置づけられているという共通 の仮定の下に，さまざまな社会的状況の分析が試みられ ている (Forgas, 1982 ; Magnusson, 1971). たとえ ば, Forgas (1980) や Forgas, Brown, \& Menyhart （1980）はこれを用いて攻撃行動や犯罪といった社会的 エピソードを分析し, 抽出された認知次元が “ア・プリ オリ”なエピソード分類や出現頻度, 被害の大きさとい った他の客観的指標とも深い関連があることを明らかに している. 本研究では, この手法を侵犯者の社会的苦境 認知に応用し, 社会的苦境を弁別するための認知次元を 抽出するとともに，その結果に基づいた社会的苦境の分 類を試みた. また, 被験者には次元抽出のために利用し
た刺激場面において侵犯者の立場からどのような反応を するかを記述するよう求め, 認知次元と反応傾向との関 連を分析することによって，社会的苦境の認知が侵犯者 の方略選択をどのように規定しているかを検討した.

\section{方法}

被験者 一般教養心理学の講義を受講する男子大学生 120 人.

刺激場面 広範囲な社会的苦境を採取するためにま ず心理学を専攻する大学院生 8 人を対象に, 日常的な大 学生活の中で “弁解や釈明をする必要があるか，または それを要求される”場面を列挙するよう求めた. その中 から, (a) Snyder, Higgins, \& Stucky (1983) の挙 げる社会的苦境の 3 つの構成要素, すなわち侵犯者の 行動, 侵犯者にとって望ましくない帰属がなされる可能 性, 㧊よび観察者の存在が明らかであること, (b) 相 互に類似しないこと，（c）短文で記述しても十分了解 可能であることを基準に刺激場面を選択した. さらに遭 遇の可能性は低くても十分に想像可能と思われる場面を 加え, 計 15 個の刺激場面を設定した (Table 1). なお， 評定の際の視点を明確にするために場面はすべて Aさん の行動を記述するという形式で統一した。

評定尺度 多次元尺度法による分析には各刺激場面相 互間の非類似度のデータが必要である. 本研究では各刺 激場面に対して複数の 尺度で評定を求め, その評定值 から各場面間の非類似度を計算する方法を採用した。 そ のために, Forgas (1976) の日常的エピソードの分析, Cody \& McLaughlin (1980) の依頼場面分析, Forgas 
Table 2

評 定 尺 度

\begin{tabular}{|c|c|}
\hline 番号 & 9 ポイント 尺度 \\
\hline 1 & 誰もが遭遇する可能性がある-遭遇する可能性は少ない \\
\hline 2 & 謝れぱ済む一謝っても済まない \\
\hline 3 & どう振舞って良いか分からないーどう振舞ったら良いか知っている \\
\hline 4 & 自分の面目にかかわるー自分の面目にかかわらない \\
\hline 5 & 狼狽するー狼狽しない \\
\hline 6 & 弁解する必要があるー弁解する必要はない \\
\hline 7 & 羞恥心を感じる-羞恥心を感じない \\
\hline 8 & 相手の面目にかかわるー相手の面目にかかわらない \\
\hline 9 & 相手に与えた被害は大きいー相手に与えた被害は小さい \\
\hline 10 & 自己正当化できるー自己正当化できない \\
\hline 11 & 相手との将来の関係に係わるー相手との将来の関係に係わらない \\
\hline 12 & 自分に非があるー自分に非はない \\
\hline 13 & 罪悪感を感じるー罪悪感を感じない \\
\hline 14 & 意㘡的なー意図的でない \\
\hline 15 & 不注意なー不注意でない \\
\hline 16 & 敵意のある一敵意のない \\
\hline 17 & 自分勝手なー自分勝手でない \\
\hline 18 & コントロールできるーコントロールできない \\
\hline 19 & 言い逃れがきくー言い逃れがきかない \\
\hline 20 & 相手の感情を害するー相手の感情を害することはない \\
\hline
\end{tabular}

（1980）の犯罪の分析，および Forgas et al. (1980) の 攻撃エピソード分析で利用された尺度の中から社会的苦 境の評価にも適切と思われるもの（たとえば，遭遇可能 性, 意図性, 正当性等に関するもの) を選び出し,さら に社会的苦境に固有な状況特性の評価・弁別に役立つと 思われる尺度（たとえば，感情的反応，体面維持への配 慮等に関するもの) を加えて, 計 20 対の両極尺度を作 成した (Table 2).

手続き 刺激場面と評定尺度は教示と記入例を付けた 小冊子にとじられて配布された. 刺激場面の提示順序は 被験者ごとにランダムとし, 評定尺度についても 2 通り の提示順序が設定された. 被験者はページ上段に記され た刺激場面について 20 対の評定尺度に 9 ポイントで評 定し，さらにページ下段の空欄に，Aさんになったつも りで“このような場合に, 実際にどのような弁解や説明 をするか”を具体的に記述するよら求められた.

分析方法 以上の手続きによって得られた資料は認知 次元の抽出, 及び次元と方略選択との関連を検討するこ とを目的に，以下の 4 点から分析された。

1. 次元抽出 : 2 相 3 元データを扱ら多次元尺度法の らち, 重み付きユークリッド距離モデルを用いて, 社会 的苦境を弁別する認知次元を抽出した. このモデルは複 数の行列間の差異から軸の方向を一意的に決めることが
でき, 通常, 軸の回転なしに次元の解釈を容易に行らこ とができる(Carroll \& Arabie, 1980; Carroll \& Chang, 1970 ; Kruskal \& Wish, 1978 ; 高根, 1980). 計算手続きとしては, de Leeuw \& Pruzansky (1978) の SUMSCAL を用いた. 本研究のように, K人の被験 者が $I$ 個の対象を $S$ 個の尺度上で評定した場合，入力デ ータとなる対象間の非類似性距離行列は, 各尺度につき 1 つずつ求める場合と各個人につき 1 つずつ求める場合 の 2 通りが考えられる. 本研究では社会的苦境場面を分 類, 記述するための次元の抽出を目的としているので, 各尺度についての 20 個の非類似性距離行列を入力デー タとした. 尺度 $s$ における対象 $i$ と $j$ の間の非類似性距 離行列 $d_{i j s}$ の算出方法は式 (1) の通りである.

$$
d_{i j s}=\left[\frac{1}{N} \sum_{k=1}^{N}\left(x_{i k s}-x_{j k s}\right)^{2}\right]^{1 / 2}
$$

ここで, $N$ は被験者数, $x_{i k s}$ は尺度 $s$ 上での被験者 $k$ による対象 $i$ の評定值を示す．この場合，算出される次 元ウェイトは尺度に関係したものであり，ある評定尺度 のウェイトが特定の次元で大きいといらことはその次元 がその尺度の属性と関係していることを意味する。

2. 場面分類：各刺激場面の次元布置に基づき，クラ スター分析によって刺激場面を分類した.

3. 内容分析：自由記述によって得られた反応を 
Table 3

SUMSCAL 分析によって得られた共通刺激空間

\begin{tabular}{|c|c|c|c|c|}
\hline & 第 1 次元 & 第 2 次元 & 第 3 次元 \\
\hline \multicolumn{2}{|c|}{ A 交通事故 } & -1.080 & -1.213 & .512 \\
\hline B & 自 転 車 & 1.855 & -1.097 & -.204 \\
\hline $\mathrm{C}$ & カ メ ラ & -.851 & -1.183 & -.080 \\
\hline $\mathrm{D}$ & デ - & -.018 & .304 & -.458 \\
\hline $\mathrm{E}$ & 婚 約 破 裹 & 1.206 & -.229 & 1.932 \\
\hline $\mathrm{F}$ & 電車 & -.983 & 1.603 & -.480 \\
\hline G & 宿 & .992 & .150 & -1.476 \\
\hline $\mathrm{H}$ & 家庭 教 師 & 1. 204 & -.518 & -.620 \\
\hline I & 映 & -.394 & 1.523 & -.592 \\
\hline $\mathrm{J}$ & 名 & -.698 & 1. 173 & $\therefore \quad .195$ \\
\hline $\mathrm{K}$ & 宴 & -1.092 & -.265 & -.059 \\
\hline L & 会 & 1. 219 & -.463 & 1. 502 \\
\hline M & レストラン & -.682 & -1.131 & -1.142 \\
\hline $\mathrm{N}$ & 話 & -.972 & 1.610 & -.844 \\
\hline $\mathrm{O}$ & 悪 & .294 & -.264 & 1.813 \\
\hline
\end{tabular}

Semin \& Manstead (1983) のシステムに基づき内容分 析し，反応カテゴリー別の出現頻度を得た.

4. 分類と反応との関連 : 刺激場面のクラスター分類 の結果と各反応カテゴリーの反応出現頻度との関連につ いて対数線形モデル（弓野，1981）により分析した. 対 数線型モデルは $\chi^{2}$ 検定と異なり交互作用の分析が容易 にできるという利点がある.

\section{結果}

SUMSCAL の結果 2 次元解から 6 次元解まで求め た場合の分散説明率は，それぞれ，37.1，44.1，49.0， $53.5,57.8$ パーセントであり, 2 次元解から 3 次元解に かけては 7 パーセントの増加が見られるのに対し，それ 以降は 5 パーセント未満の増加しか見られない。また, 3 次元解では全ての次元が 10 パーセント以上の分散を 占めているが，次元数を増やしても，5 パーセント程度 の分散を占める次元しか組み込まれない. 従って, ここ では 3 次元解が最適であると解釈された. 共通刺激空間 の構造を Table 3 に, 各評定尺度の次元ウェイトを Table 4 に示す. 抽出された次元は Table 3 に基つい て解釈された。第 1 次元では “意図的でない一意図的 な”, “不注意なー不注意でない”, “自分勝手な一自分勝手 でない”、“ュントロールできるーコントロールできない” の 4 つの評定尺度で次元ウェイトが高く, 統制可能性の 次元とされた，第 2 次元は “狼狽する一狼狽しない”, “謝まれば済む一謝っても済まない”, “罪悪感を感じるー 罪悪感を感じない”といった感情的動摇を示す評定尺度 でウェイトが高く, 感情的反応性の次元と解釈された。
Table 4

各尺度の次元ウェイト

\begin{tabular}{|c|c|c|c|c|}
\hline 尺度番号 & 第 1 次元 & 第 2 次元 & 第 3 次元 & $R^{\text {a) }}$ \\
\hline 1 & .413 & .244 & .165 & .257 \\
\hline 2 & .170 & .614 & .180 & .438 \\
\hline 3 & .316 & .279 & .418 & .352 \\
\hline 4 & .331 & .443 & .214 & .352 \\
\hline 5 & .247 & .662 & .244 & .559 \\
\hline 6 & .285 & .407 & .243 & .306 \\
\hline 7 & .305 & .434 & .236 & .337 \\
\hline 8 & .215 & .206 & .703 & .583 \\
\hline 9 & .190 & .407 & .494 & .446 \\
\hline 10 & .310 & .483 & .283 & .409 \\
\hline 11 & .238 & .282 & .441 & .331 \\
\hline 12 & .275 & .477 & .305 & .396 \\
\hline 13 & .226 & .534 & .259 & .403 \\
\hline 14 & .841 & .082 & .150 & .737 \\
\hline 15 & .658 & .279 & .208 & .554 \\
\hline 16 & .465 & .087 & .407 & .389 \\
\hline 17 & .732 & .227 & .163 & .614 \\
\hline 18 & .562 & .294 & .330 & .511 \\
\hline 19 & .333 & .497 & .267 & .429 \\
\hline 20 & .284 & .293 & .437 & .357 \\
\hline 分散説明率 & .173 & .155 & .113 & .441 \\
\hline
\end{tabular}

第 3 次元は “相手の面目にかかわる一相手の面目にかか わらない”，“相手に与えた被害は大きい一相手に与えた 被害は小さい”の尺度で高いウェイトを示していること から, 侵犯性の次元と命名された. な叔, 第 1 次元と第 3 次元はウェイトが高いほどそれぞれ統制可能で，侵犯 の程度が大きいことを，また第 2 次元はウェイトが低い ほど感情的反応が大きいことを意味する.

場面分類 共通空間内での各刺激場面の座標値から刺 激場面間のニークリッド平方距離を算出してクラスター 分析を行った. 最短距離法, 。最長距離法, 群平均法, お よびウォード法による分析の結果, 最短距離法を除く他 の 3 手法に共通の 4 つないし 5 つのクラスターが見い出

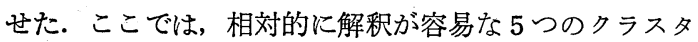
一を採択した. Fig. 1 から明らかなように，第 1 クラス ター, 第 2 クラスター, 第 5 クラスターは統制可能性次 元と感情的反応性次元での布置から弁別される. また, 図中では第 3 クラスターと第 4 クラスターはきわめて近 接しているが, 侵犯性次元での布置によって両者は明確 に区別される.

内容分析 自由記述の反応はまずSemin \& Manstead 
Table 5

クラスター別各カテゴリー反応数と対数線形モデルによる分析結果

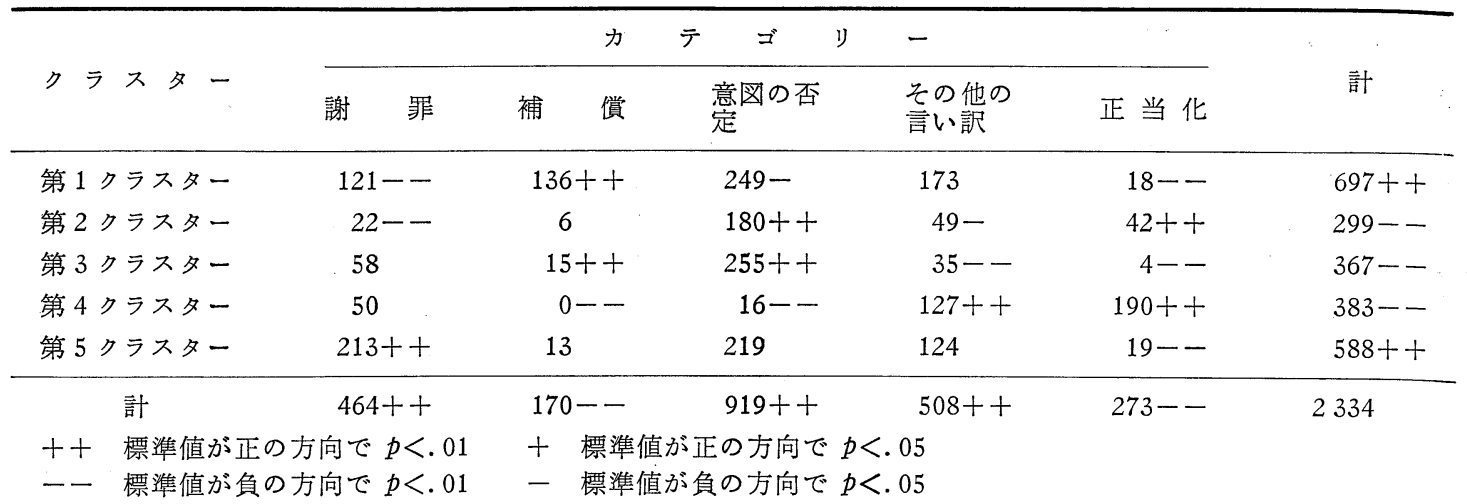

(1983) のカテゴリーシステムの下位カテゴリーに基づ き 2 人の判定者によって独立に分類された. しかし，カ テゴリーが多岐にわたり, 判定者間の判定一致率（78.4 \%) も低かったので，以下の分析では次のような上位・ 中位カテゴリーに集計した資料を用いた．このカテゴリ ーシステムでの判定一致率は $91.5 \%$ である.

1. 謝罪 : 行動の不適切さや自己の責任を認めた上で 後悔, 自責の念, 罪悪感等を表明して他者の許しを乞う ものである. Semin \& Manstead のシステムには謝罪 の下位カテゴリーは設定されていないが，本研究ではこ れをさらに自分の非を認めたり許しを乞うだけの“謝 罪”と自分が与えた被害や損害の補償・弁償を申し出る “補償”とに分けた.

2. 言い訳：言い訳は自分の行動が不適切なものであ

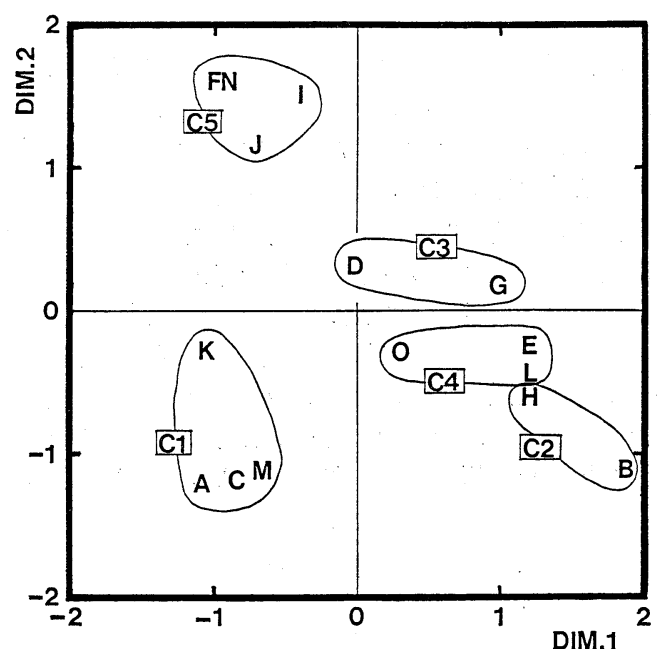

Fig. 1. 統制可能性次元（X軸）と感情的反応性 次元 ( $\mathrm{Y}$ 軸) 上でのクラスターの分布.
ることは認めるが，その行動に対する自己の責任を否定 しようとするものである. Semin \& Manstead はこれ に4つの中位カテゴリーを設けているが，本研究では事 故や予知せざる結果であることを主張する “意図の否 定”之他の統制力の欠如, 行為の否定, 情状の訴えをあ わせた “その他の言い訳”の 2 つ分けた。

3. 正当化: 正当化とは, 行動の責任は認めるが，そ の行動や結果は不適切で誤ったものではないと主張する ものである. Semin \& Manstead はこれを8つの中位 カテゴリーに分類したが, 本研究ではこれをまとめてひ とつのカテゴリーとして扱った.

なお，ひとりの被験者が 2 つ上の反応をしたり，い ずれにも分類できない反応をしたケースがあるために, 総反応数は刺激場面ごとに異なっている.

分類と反応との関連 各反応カテゴリーの出現頻度を クラスター別に集計してクラスター $5 \times$ カテゴリー 5 の 2 要因対数線型モデルにより分析した結果, クラスター 要因とカテゴリー要因の主効果と交互作用が有意となっ た (Table 5). クラスター要因の主効果は第1 クラスタ 一と第 5 クラスターで反応数が多いことを意味する.こ

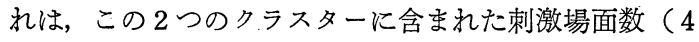
場面）が他のクラスター（2または 3 場面）より多かっ たためである. カテゴリー要因の主効果は補償と正当化 の出現頻度が他の反応カテゴリーに比べて少ないことを 示している. この結果で最も重要なのは交互作用で, こ れはクラスターによって頻度の高いあるいは低い反応力 テゴリーが異なっていることを意味している.

\section{考察}

SUMSCAL モデルによる多次元尺度解析の結果, 統 制可能性, 感情的反応性, 侵犯性の 3 つの認知次元が抽 出された. 侵犯性次元と統制可能性次元はその内容から 判断して, それぞれ従来の研究で取り上げられた行動の 
侵犯度と帰属される責任度の要因に対応した認知次元で あると思われる．他方，感情的反応性次元は状況が喚起 する困惑感や罪覀感の強さを示している. 前者は人が呈 示すべき印象と実際の行動との間にギャップがある時に 体験される情動, 後者は自己非難に伴う情動であり, Goffman (1971) によれば，その表明は謝罪の本質的な 構成要素であると考えられる.

本研究の主たる目的は抽出されたこれらの次元と侵犯 者の方略選択との関連を検討することであった. 分析の 結果は両者の間に密接な関係があることを示している.

以下, 結果に基ついて認知次元と各印象管理方略との 関係について考察する. まず, 統制不可能な行動によっ て惹起されたと判断された場面 (クラスター 1 とクラス ター5）では謝罪または補償が多く選択されている．既 に述べたように，この次元は侵犯者に帰属される責任の 程度と関連があると考えられることから，負らべき責任 が小さい時には，それを自ら認めたり償いを申し出るこ とによって誠実さや他者への敬意を印象づけるが最も 自分に有利であると判断されたものと推測される. た，謝罪は感情的反応が小さい場面（クラスター5）で 多く, 補償は感情的反応が大きい場面 (クラスター1) で多く選択された。これは，補償の申し出が罪悪感や困 惑感の表明手段として利用されたことを示している.

他方, 社会的苦境が統制可能な行動によって惹起され たと知覚された場面では，謝罪や補償より言い訳や正当 化が多く選択された。 その中でも侵犯度が高いと知覚さ れた場面（クラスター4）では正当化が多く，侵犯度が 低い場面（クラスター3）では意図の否定による言い訳 が多い。侵犯度が低い場合, 言い訳によって自分に帰属 される責任を低減することで，自分が維持すべき印象を 守ることができると侵犯者は判断したのであろう.それ に対して侵犯度が高い場合，たとえ言い訳によって責任 を回避できたとしても，あるいは謝罪によってある程度 まで印象の低下を防ぐことがでさたとしても，新たに確 立される相互作用に拉いては相対的に侵犯者は弱い立場 に置かれることが予想される.したがって，このような 場面で侵犯者が正当化を選択したことは，責任回避や印 象の維持を犠牲にしても, 新たな相互作用においてでき るだけ有利な立場に立とうとする試みを示していると考 えることができる.これは，正当化が単に自分の維持す べき印象を守るためだけでなく，社会的苦境を契機とし て新たな相互作用を確立する目的で積極的に利用される 可能性を秘めていることを示唆する. なお，クラスター 2 では意図の否定による言い訳と正当化が多く選択され た.これは, クラスター 2 の布置が統制可能性次元でク ラスター 4 に類似し，侵犯性の次元ではクラスター 3 に 近いために，その両方の特徴が表われたものであろら. 同様に, クラスター 3 で補償が多かったことは, 統制可
能性次元で相対的に低かったことによると考えられる.

以上を要約すると, 抽出された認知次元上での社会的 苦境の布置は侵犯者による印象管理方略の選択と密接な 関連があり，統制可能性次元は謝罪・補償 または言い 訳・正当化の選択に，感情的反応性次元は謝罪または補 償の選択にそして侵犯性の次元は言い訳または正当化の 選択に係わっていると言らことができる.なお，本研究 では認知空間に打ける社会的苦境の布置と方略選択との 関連に焦点を絞って検討し，個人差に係わる要因につい ては一切触れなかったが, 侵犯者の自己監視, マキャベリ ズム, 自己意識, 承認欲求等の強さによって方略選択の傾 向が異なることは十分に予想される (Schlenker, 1980), この問題に対しても, 本研究で利用した多次元尺度法は 個人差をも同時に分析対象にできるといら利点があり， 有効な分析手段となりうる. 今後は，本研究の知見を踏 まえて，個体要因も含めた分析を行ら必要があろう。

\section{引用 文 献}

Blumstein, P.W. 1974 The honouring of accounts. American Sociological Review, 39, 551566.

Carroll, J. D., \& Arabie, P. 1980 Multidimensional scaling. Annual Review of Psychology, 31, 607649.

Carroll, J. D., \& Chang, J. J. 1970 Analysis of individual differences in multidimensional scaling via an N-way generalization of "Eckart-Young" decomposition. Psychometrika, 35, 282-319.

Cody, M. J., \& McLaughlin, M. L. 1980 Perceptions of compliance-gaining situations: A dimensional analysis. Communication Monographs, 47, 132-148.

Darby, B. W., \& Schlenker, B. R. 1982 Children's reactions to apologies. Journal of Personality and Social Psychology, 43, 742-753.

de Leeuw, J., \& Pruzansky, S. A. 1978 A new computational method to fit the weighted Euclidian distance model. Psychometrika, 43, 479-490.

Felson, R. B., \& Ribner, S. A. 1981 An attributional approach to accounts and sanctions for criminal violence. Social Psychological Quarterly, 44, 137-142.

Forgas, J.P. 1976 The perception of social episodes: Categorical and dimensional representations in two different milieus. Journal of Personality and Social Psychology, 34, 199-209.

Forgas, J. P. 1980 Images of crime : A multidimensional analysis of individual differences in crime perception. International Journal of $P$ sychology, 15, 287-299.

Forgas, J. P. 1982 Episode cognition : Internal representation of interaction routines. In L. Ber- 
kowitz (Ed.), Advances in experimental social psychology. Vol. 15. New York: Academic Press. Pp. 59-101.

Forgas, J.P., Brown, L. B., \& Menyhart, J. 1980 Dimensions of aggression: The perception of aggressive episodes. British Journal of Social and Clinical Psychology, 19, 215-227.

Goffman, E. 1955 On face-work : An analysis of ritual elements in social interaction. Psychiatry: Journal for the Study of Interpersonal Processes, 18, 13-231.

Goffman, E. 1971 Relations in public: Microstudies of the public order. Harmondsworth: Penguin.

Kruskal, J. B., \& Wish, M. 1978 Multidimensional scaling. Beverly Hills, Calif.: Sage Publications.

Magnusson, D. 1971 An analysis of situational dimensions. Perceptual and Motor Skills, 32, 851-867.

Mills, C. R. 1940 Situated actions and vocabularies of motive. American Sociological Review, 5, 904-913.

Schlenker, B. R. 1980 Impression management : The self-concept, social identity, and interpersonal relations. Monterey, Calif.: Books/Cole. Schonbach, P. 1980 A category system for ac- count phases. European Journal of Social Psy. chology, 10, 195-200.

Scott, M. B., \& Lyman, S. M. 1968 Accounts. American Sociological Review, 33, 46-62.

Semin, G. R., \& Manstead, A.S. R. 1983 The accountability of conduct: A social psychological analysis. New York: Academic Press.

Snyder, C. R., Higgins, R. L., \& Stucky, R. J. 1983 Excuses: Masquerades in search of grace. New York : John-Wiley \& Sons.

Sykes, G. M., \& Matza, D. 1957 Techniques of neutralization : A theory of delinquency. Ameri. can Sociological Review, 22, 664-670.

高根芳雄 1980 多次元尺度法 東京大学出版会

Tedeschi, J. T., \& Reiss, M. 1981 Verbal strategies in impression management. In C. Antaki (Ed.), The psychology of ordinary explanations. New York: Academic Press. Pp. 271-309.

Ungar, S. 1981 The effects of status and excuse on interpersonal reactions to deviant behavior. Social Psycholngical Quarterly, 44, 260-263.

弓野憲一 1981 対数-線型モデルによる 質的データの 解析とそのための BASIC プログラム 静岡大学教育 学部研究報告 (自然科学篇), 32, 189-215.

-1987.4.13. 受稿, 1987.11.14. 受理一 